\title{
Subklinik Hipotiroiditli Çocuklarda Ağız Sağlığı Durumunun Değerlendirilmesi
}

\section{Evaluation of Oral Health Status of Children with Subclinical Hypothyroidism}

\author{
Nuray Tüloğlu1, Tuğçe Kaliçoğlư ${ }^{2}$, Birgül Kurel $^{3}$ \\ ${ }^{1}$ Eskişehir Osmangazi Üniversitesi, Diş Hekimliği Fakültesi, Çocuk Diş Hekimliği Anabilim Dall, Eskişehir \\ ${ }^{2}$ Serbest Çocuk Diş Hekimi, Çanakkale \\ ${ }^{3}$ Eskişehir Osmangazi Üniversitesi, Tip Fakültesi, Çocuk Sağlı̆̆ı ve Hastalıkları Anabilim Dalı, Eskişehir
}

ORCID

Nuray Tüloğlu https://orcid.org/0000-0001-6410-9126

Tuğçe Kaliçoğlu https://orcid.org/0000-0002-4784-2884

Birgül Kurel https://orcid.org/0000-0002-8313-5677

Yazışma Adresi / Correspondence:
Doç. Dr. Nuray TÜLOGULU

Eskişehir Osmangazi Üniversitesi Diş Hekimliği Fakültesi Çocuk Diş Hekimliği Anabilim Dalı, Meşelik Kampüsü/ESKIŞEHIIR

Tel: +90222 2393750 / $4407 \quad$ E-mail: nuraytuloglu@yahoo.com

Geliş Tarihi / Received : 30-10-2019 Kabul Tarihi / Accepted : 05-11-2019 Yayın Tarihi / Online Published: 27-12-2019

Tüloğlu N., Kaliçoğlu T., Kırel B., Subklinik Hipotiroiditli Çocuklarda Ağız Sağlığı Durumunun Değerlendirilmesi,

J Biotechnol and Strategic Health Res. 2019;3(3):219-224 DOİ:10.34084/bshr.640291

\footnotetext{
Öz

Amaç Bu araştırmada, subklinik hipotiroiditli çocuk hastaların ağız sağlığı durumunun değerlendirilmesi ve sağlıklı çocuklarla karşılaştırılması amaçlandı.

Gereç ve Araştırmaya 4-18 yaş aralığındaki 36’sı subklinik hipotiroiditli (deney grubu), 36’’sı sağlıklı (kontrol grubu) toplam 72 çocuk dahil edildi. Araştırmaya dahil edilen Yöntemler çocukların ağız sağlı̆̆ durumunu belirlemek için DMFT/dft indeksi, gingival indeks, plak indeksi kullanıldı. Elde edilen verilerin istatistiksel analizlerinde 2 yönlü varyans analizi (two-way ANOVA) ve Bonferroni testi kullanıldı.

Bulgular Deney grubunun DMFT değerlerinin kontrol grubundan daha yüksek olduğu ancak aradaki farkın sadece 13-18 yaș grubunda istatistiksel olarak anlamlı olduğu belirlendi $(\mathrm{p}<0.05)$. Plak indeksi ve gingival indeks skorları açısından kontrol ve deney grubu arasında anlamlı bir fark olmadığı tespit edildi $(\mathrm{p}>0.05)$.

Sonuç Subklinik hipotiroiditli çocuk hastalarda diş çürüğü görülme sıklığının sağlıklı çocuklara oranla daha yüksek olduğu ancak periodontal sağlığın etkilenmediği belirlendi. Bununla birlikte, bulgularımızın desteklenmesi için daha geniş popülasyonlu çalışmaların yapılması gerektiği kanısındayız.

Anahtar Çocuk, Diş çürüğü, Subklinik hipotiroidi, Periodontal sağlık.

Kelimeler

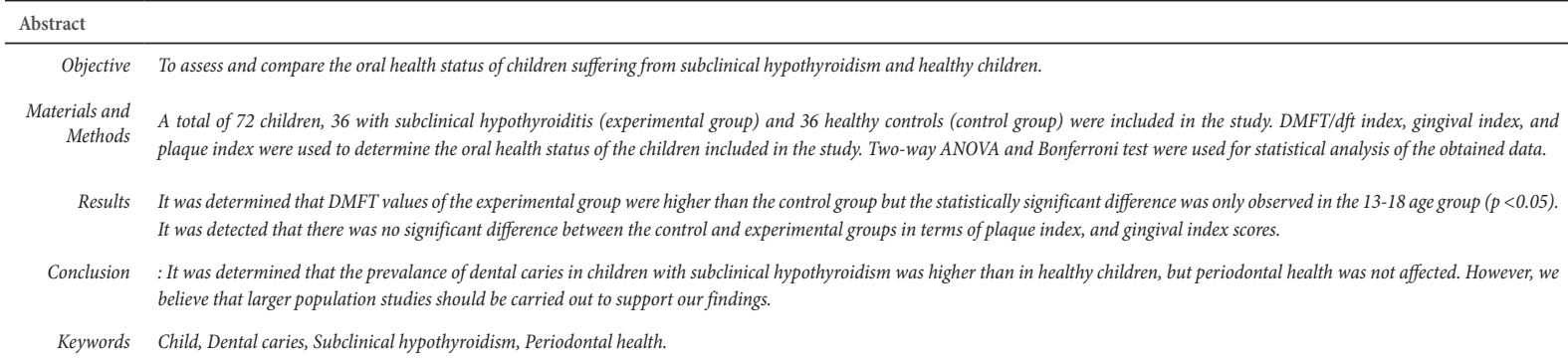




\section{GIIRIŞ}

Subklinik hipotiroidi, serum serbest tiroksin (sT4) ve triiyodotironin (sT3) hormon seviyelerinin normal olmasina karşın, serum tiroid uyarıcı hormon (TSH) seviyesinin yüksek olması ile karakterize tiroid fonksiyon bozukluğu olarak tanımlanmaktadır ${ }^{1,2}$. Aşikar hipotiroidi ile aynı etiyolojiye sahip olan subklinik hipotiroidinin en sık nedenini kronik otoimmün tiroidit (Haşimato tiroiditi) oluşturmaktadır ${ }^{3,4}$. Bunun yanı sıra, boyun bölgesine alınan radyoterapi, tiroid cerrahisi, sigara kullanımı, yaş, cinsiyet, iyot metabolizması ve ilaç kullanımı (lityum, amiodaron) gibi faktörler de subklinik hipotiroidi nedenleri arasında yer almaktadır ${ }^{3,5,6}$.

Subklinik hipotiroidinin görülme sıklığı popülasyon, ırk, bölge, yaş, cinsiyet ve TSH ölçüm metoduna göre farkl1lık gösterebilmektedir ${ }^{5}$. Yetişkin popülasyonunda görülme sıklığının \%1-10 arasında değiștiği, kadınlarda erkeklere oranla daha sık gözlendiği ve yaşla birlikte görülme sıkl1ğının arttığı bildirilmektedir ${ }^{7-9}$. Çocukluk çağı ve ergenlik döneminde görülme sıklığı ile ilgili epidemiyolojik çalışmalar yetersiz olmasına rağmen, çocuklarda görülme sıklığının \%2'den az olduğu rapor edilmektedir?.

Subklinik hipotiroidi genellikle asemptomatik olmasına rağmen, hastaların bazılarında cilt kuruluğu, halsizlik, soğuk intoleransı, uyku ve hafıza bozukluğu, kilo alımı, ses kalınlaşması, gözlerde şişlik ve kas krampları gibi hipotiroid belirtileri gözlenebilmektedir ${ }^{3,9-11}$.

Hipotiroiditli hastalarda ağız bulgularının değerlendirildiği sınırlı sayıdaki çalışmalarda tükürük fonksiyonlarının etkilendiği, diş çürügü ve periodontal hastalıkların görülme sıklığının arttığı ve liken plenus lezyonları görüldüğü rapor edilmiştirr ${ }^{12-16}$. Yapılan literatür araştırmasında, hipotiroiditli hastaların ağız sağlığının değerlendirilmesi ile ilgili az sayıda çalışma olduğu ve bu çalışmaların çoğunlukla yetişkin bireyler üzerinde gerçekleştirildiği görülmektedir ${ }^{12-14,16}$. Bu nedenle bu araştırmada, subklinik hipotiroiditli çocuk hastaların ağız sağlı̆̆ı durumunun değerlendirilmesi ve sağlıklı çocuklarla karşılaştırılması amaçland1.

\section{Yöntem}

$\mathrm{Bu}$ araştırma Eskişehir Osmangazi Üniversitesi Tıp Fakültesi Çocuk Sağlığı ve Hastalıkları Anabilim Dalı'na başvuran 4-18 yaş aralığında Subklinik Hipotiroidit tanısı konan ve Eskişehir Osmangazi Üniversitesi Diş Hekimliği Fakültesi Çocuk Diş Hekimliği Anabilim Dalı’na başvuran aynı yaş grubundan rastgele seçilmiş herhangi bir sistemik hastalığı olmayan çocuk hastalar üzerinde gerçekleştirildi. Araştırma başlamadan önce Eskişehir Osmangazi Üniversitesi Klinik Araştırmalar Etik Kurulu'ndan (Karar Tarihi: 02.01.2018; Sayı No: 80558721/32) onay alındı. Aydınlatılmış onam formu ebeveynler ve çocuk yaş grubu için ayrı olarak hazırlandı ve 16 yaş ve üzeri çocuklardan yazılı onam alındı. Diğer yaş grubu için anlayabilecekleri dilde hazırlanan onam formu ile çocuklardan sözlü izin, ebeveynlerinden ise yazılı onam alındı.

\section{Çalışma Gruplarının Oluşturulması}

Araştırma başlangıcında, PASS 11 paket programı kullanılarak güç analizi yapıldı. Kullanılan veriler "Evaluation of xerostomia and salivary flow rate in Hashimoto's Thyroiditis" isimli makaleden alındı. Odds oranları göz önünde bulundurularak yapılan güç analizinde \%81 güç ile her bir grupta en az 36 kişi ile çalışılmasının uygun olduğu saptandi.

\section{Deney Grubu}

Araştırmamızın deney grubuna, Eskişehir Osmangazi Üniversitesi Tıp Fakültesi, Çocuk Sağlığı ve Hastalıkları Anabilim Dalı'na başvuran 4-18 yaş arası çocuklardan subklinik hipotiroidi tanısı konan çocuklar dahil edildi. Çocukların TSH ve serum sT4 düzeyleri Eskişehir Osmangazi Üniversitesi Tip Fakültesi Hastanesi Biyokimya Laboratuarı'nda modüler hormon cihazı (Roche Cobas8000r, North America) kullanılarak immunoassay yöntemiyle belirlenmiştir. Buna göre sT4 değerleri normal iken TSH değerleri yaşa ve cinsiyete göre normal referans aralığının üst sını- 
rından daha yüksek olan hastalara subklinik hipotiroidi tanısı konmuştur. Aynı zamanda TSH değeri yaşa ve cinsiyete göre normal referans aralığının üst sınırından daha yüksek olan hastalarda tiroid palpabl ise haşimato tiroiditi şüphesi göz önünde bulundurularak anti Tg ve antiTPO antikorlarına da bakılmıştır. Subklinik hipotiroidinden başka herhangi bir sistemik hastalığı bulunan ve son üç ayda herhangi bir ilaç kullanmış olan çocuklar ise araştırmaya dahil edilmedi.

\section{Kontrol Grubu}

Araştırmamızın kontrol grubuna Eskişehir Osmangazi Üniversitesi Diş Hekimliği Fakültesi Çocuk Diş Hekimliği Anabilim Dalı'na ve Eskişehir Osmangazi Üniversitesi Tıp Fakültesi, Çocuk Sağlığı ve Hastalıkları Anabilim Dalı’na başvuran herhangi bir sistemik hastalığı bulunmayan, son üç ayda herhangi bir ilaç kullanmamış olan ve subklinik hipotiroidi tanısı olan çocuklar ile aynı yaşta olan çocuklar arasından rastgele seçilen çocuklar dahil edildi. Ayrıca araştırmamızın kontrol grubu oluşturulurken sağlıklı çocukların da subklinik hipotiroidi olabileceği göz önünde bulundurularak sT4 ve TSH kan değerleri çalışılarak subklinik hipotiroidi olmadığı onaylandı.

Araştırma dahil edilen çocuklar yaşlarına göre 0-6, 7-12, 13-18 olmak üzere üç gruba ayrıldı.

\section{Ağız ve Diş Sağlığının Değerlendirilmesi}

Araştırmaya dahil edilen tüm çocukların ağız içi muayenesi klinik ortamında ayna ve sond yardımı ile tek bir diş hekimi (T.K.) tarafından gerçekleştirildi. Araştırmaya dahil edilen çocukların ağız ve diş sağlığ değerlendirilirken dental anomali varlığı, çürük, dolgulu ve kayıp dişlerin tayini ve periodontal durumu incelendi.

\section{DMFT/dft Değerlendirmesi}

Diş çürügünün değerlendirilmesinde, süt ve daimi dişlerde dft/DMFT indeksi kullanıldı. Araştırma gruplarının dft/DMFT değerlerinin belirlenmesinde; çürük (d-D), çürük nedeniyle çekilmiş $(\mathrm{M})$ ve çürük nedeniyle dolgu yapılmış (f-F) dişlerin toplamının, grupta toplam muayene edilen kişi sayısına bölünmesiyle elde edildi.

\section{Periodontal Durumun Değerlendirilmesi}

Araştırmaya dahil edilen çocukların periodontal dokularının değerlendirilmesinde Silness-Löe Plak İndeksi ve Löe-Silness Gingival İndeksi kullanıldı.

\section{Silness-Löe Plak İndeksi}

Ağız içerisinde var olan tüm dişler hava spreyi ile kurutulup rulo pamuk tamponlar ile izole edildi. Dişlerin mezial, distal, labial ve lingual yüzeyleri olmak üzere toplam dört yüzeyinde göz ve periodontal sond yardımı ile plak varlığı değerlendirildi. Her bir dişin her bir yüzeyine verilen 0-3 arası değerler toplanıp 4’e bölünerek dişin skoru, dişlerin skor toplamı toplam incelenen diş sayısına bölünerek her bir birey için plak indeks skoru saptand $1^{17}$. Silness-Löe Plak İndeksi değerleri Tablo 1' de görülmektedir.

\begin{tabular}{|l|l|}
\hline \multicolumn{2}{|c|}{ Tablo 1. Silness-Löe plak İndeksi değerleri ${ }^{17}$} \\
\hline 0 & $\begin{array}{l}\text { Göz ve sonda ile değerlendirildiğinde gingival alanda plak } \\
\text { olmaması }\end{array}$ \\
\hline 1 & $\begin{array}{l}\text { Çıplak gözle gözlenmeyen, ancak sond ucu gingival sulkusta } \\
\text { gezdirildiğinde fark edilen plak varlığ1 }\end{array}$ \\
\hline 2 & $\begin{array}{l}\text { Diş eti bölgesi inceden orta kalınlığa kadar plakla kaplıdır } \\
\text { veçılak gözle izlenen, aproksimal bölgeyi içine almayan } \\
\text { plak varlığı }\end{array}$ \\
\hline 3 & $\begin{array}{l}\text { Yumuşak eklenti fazladır, kalınlığı gingival sulkusu dol- } \\
\text { durur, interdental bölgeyi tamamen dolduran yoğun plak } \\
\text { varlığ1 }\end{array}$ \\
\hline
\end{tabular}

\section{Löe-Silness Gingival İndeksi}

Ağız içerisinde var olan tüm dişler hava spreyi ile kurutulup rulo pamuk tamponlar ile izole edildi. Dişlerin mezial, distal, labial ve lingual yüzeyleri olmak üzere toplam dört yüzeyinde göz ve periodontal sond yardımı ile diş eti değerlendirildi. Her bir dişin her bir yüzeyine verilen 0-3 arası değerler toplanıp 4’e bölünerek dişin skoru, dişlerin skor toplamı toplam incelenen diş sayısına bölünerek her bir birey için gingival indeks skoru saptand $1^{18}$. Löe-Silness Gingival İndeksi değerleri Tablo 2'de görülmektedir. 


\begin{tabular}{|l|l|}
\hline \multicolumn{2}{|l|}{ Tablo 2. Löe-Silness Gingival İndeksi değerleri ${ }^{18}$} \\
\hline 0 & Normal dişeti, iltihap, renk değişimi ve kanama yok \\
\hline 1 & $\begin{array}{l}\text { Hafif inflamasyon, hafif renk değişikliği ve ödem varlığı, } \\
\text { sondlamada kanama yok }\end{array}$ \\
\hline 2 & $\begin{array}{l}\text { Orta dereceli inflamasyon varlığı, diş etinin parlak, kırmızı } \\
\text { ve ödemli olması, sonlamada kanama varlığı }\end{array}$ \\
\hline 3 & $\begin{array}{l}\text { Şiddetli inflamasyon, diş etinde belirgin kırmızılık ve ödem } \\
\text { varlığı, spontan kanamaya eğilim ve ülserasyon varlığı }\end{array}$ \\
\hline
\end{tabular}

\section{İstatistiksel Analiz}

Araştırmada elde edilen verilerin istatistiksel analizleri IBM SPSS Statisics 22 yazılımı (SPSS Inc., Chicago, Illinois, USA) kullanılarak gerçekleștirildi.

Sürekli değişkenlerin normal dağılıma uygunluğu Shapiro Wilk Testi ile değerlendirildi. DMFT/dft, plak, gingival indeks değerlerinin kontrol ve deney grupları ile yaş grupları dikkate alınarak yapılan karşılaştırmada 2 yönlü varyans analizi (two-way ANOVA) kullanıldı. Çoklu karşılaştırma testi olarak Bonferroni testi kullanıld.

Tüm analizlerde istatistiksel anlamllık düzeyi $\mathrm{p}<0.05$ olarak kabul edildi.

\section{BULGULAR}

Araştırmaya Katılan Çocukların Demografik Bulguları Araştırmamıza 4-18 yaş aralığındaki (ortalama $10.36 \pm$ 3.93 yaş) 36’s subklinik hipotiroiditli (deney grubu), 36’s sağlıklı (kontrol grubu) toplam 72 çocuk dahil edildi. Araştırmaya dahil edilen 36 subklinik hipotiroidit hastasından beş tanesinin anti Tg ve antiTPO antikorlarının pozitif olduğu tespit edildi ve Haşimato tiroiditi tanısı koyuldu.

Araştırmaya katılan çocukların cinsiyete göre dağılımı Şekil l'de, yaş ortalamaları ise Tablo 3'de gösterilmektedir. Cinsiyet $^{*}$ ve yaşa ${ }^{* *}$ göre, kontrol ve deney grubu arasında istatistiksel olarak anlamlı bir farklılık olmadığı saptandı $\left(\mathrm{p}^{*}=1.00\right.$, Yates's Ki Kare Testi; $\mathrm{p}^{* *}=0.919$, İki örneklem $\mathrm{t}$ testi).

\begin{tabular}{|l|c|c|}
\hline \multicolumn{3}{|l|}{ Tablo 3. Araştırmaya katılan çocukların yaş ortalamaları } \\
\hline Çalışma Grupları & $\mathrm{n}$ & $\begin{array}{c}\text { Yaş } \\
\text { (Ortalama } \pm \text { Standart Sapma) }\end{array}$ \\
\hline Kontrol & 36 & $10.31 \pm 3.91$ \\
\hline Deney & 36 & $10.41 \pm 4.00$ \\
\hline Toplam & 72 & $10.36 \pm 3.93$ \\
\hline $\mathrm{p}^{* *}=0.919$, İki örneklem $\mathrm{t}$ testi \\
\hline
\end{tabular}

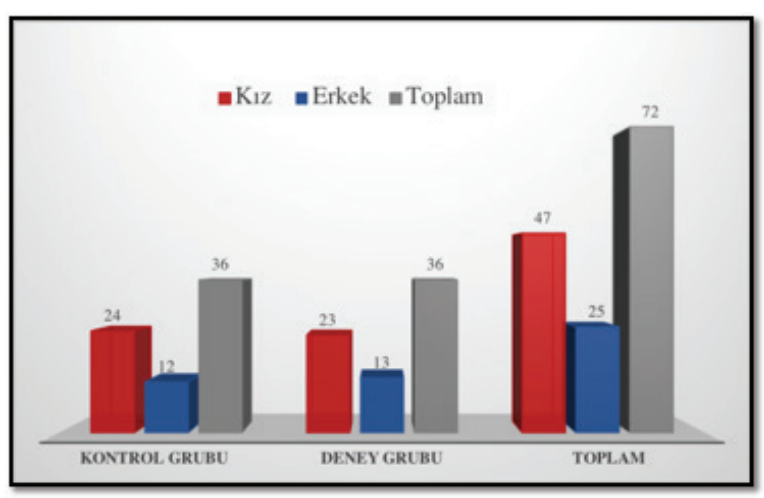

Şekil 1. Araştırmaya katılan çocukların cinsiyete göre dağılımı

\section{Ağız ve Diș Sağlığının Değerlendirilmesi}

Araştırmaya dahil edilen çocuklarda dental anomali varlığ1 değerlendirildiğinde subklinik hipotiroidit grubundaki bir çocukta sürnumerer diş, iki çocukta biçim anomalisi, iki çocukta durum anomalisi, bir çocukta infraokluzalde diş ve bir çocukta da hipoplazi varlığı olmak üzere toplam yedi çocukta dental anomali varlığı saptandı. Kontrol grubunda ise iki çocukta durum anomalisi, bir çocukta polidiastema ve iki çocukta anterior çapraz kapanış olmak üzere toplam beş çocukta dental anomali varlı̆̆ tespit edildi.

\section{DMFT/dft Değerlendirmesi}

Diş çürügü açısından (dft/DMFT) deney ve kontrol grubu karşılaştıılldığında, deney grubunun DMFT değerlerinin kontrol grubundan daha yüksek olduğu ancak aradaki farkın sadece 13-18 yaş grubunda istatistiksel olarak anlamlı olduğu belirlendi ( $\mathrm{p}=0.009)$ (Tablo 4). 
Tablo 4. Kontrol ve deney grubunun dft/DMFT değerlerinin karşılaştırılması

\begin{tabular}{|l|c|c|c|c|}
\hline \multirow{2}{*}{$\begin{array}{l}\text { Çürük } \\
\text { Durumu }\end{array}$} & $\begin{array}{c}\text { Yaş } \\
\text { Grubu }\end{array}$ & \multicolumn{2}{|c|}{$\begin{array}{c}\text { Çalışma Grupları } \\
\text { (Ortalama } \\
\text { Saptandart }\end{array}$} & \multirow{2}{*}{$\mathrm{p}^{*}$} \\
\cline { 2 - 4 } & & Kontrol & Deney & \\
\hline \multirow{4}{*}{$\mathrm{dft}$} & $0-6$ & $5.29 \pm 3.55$ & $3.67 \pm 4.12$ & 0.305 \\
\cline { 2 - 5 } & $7-12$ & $3.10 \pm 3.58$ & $2.37 \pm 3.18$ & 0.465 \\
\cline { 2 - 4 } & $13-18$ & 0 & $0.13 \pm 0.35$ & 0.934 \\
\hline \multirow{3}{*}{ DMFT } & $0-6$ & 0 & 0 & 1 \\
\cline { 2 - 4 } & $7-12$ & $3.55 \pm 1.50$ & $4.63 \pm 2.69$ & 0.132 \\
\cline { 2 - 4 } & $13-18$ & $6.11 \pm 2.61$ & $9 \pm 3.7$ & 0.009 \\
\hline \multirow{2}{*}{$\mathrm{p}^{*}=$ İki yönlü varyans analizi, Bonferroni çoklu karşılaştırma testi } \\
\hline
\end{tabular}

\section{Periodontal Durumun Değerlendirmesi}

Hem plak hem de gingival indeks skorları açısından kontrol ve deney grubu arasında anlamlı bir fark olmadığ lirlendi ( $\mathrm{p}>0.05)$ (Tablo 5).

\begin{tabular}{|c|c|c|c|c|}
\hline \multicolumn{5}{|c|}{$\begin{array}{l}\text { Tablo 5. Kontrol ve deney grubunun periodontal durumlarının } \\
\text { karşılaştırılması }\end{array}$} \\
\hline \multirow[t]{2}{*}{$\begin{array}{l}\text { Periodontal } \\
\text { Durum }\end{array}$} & \multirow[t]{2}{*}{$\begin{array}{l}\text { Yaş } \\
\text { Grubu }\end{array}$} & \multicolumn{2}{|c|}{$\begin{array}{c}\text { Çalışma Grupları } \\
\text { (Ortalama } \pm \text { Standart } \\
\text { Sapma) }\end{array}$} & \multirow[t]{2}{*}{$\mathrm{p}^{*}$} \\
\hline & & Kontrol & Deney & \\
\hline \multirow{3}{*}{ Plak İndeksi } & $0-6$ & $0.85 \pm 0.61$ & $1.38 \pm 0.81$ & 0.179 \\
\hline & $7-12$ & $1.58 \pm 0.80$ & $1.69 \pm 0.68$ & 0.668 \\
\hline & $13-18$ & $1.40 \pm 0.94$ & $1.57 \pm 0.79$ & 0.660 \\
\hline \multirow{3}{*}{$\begin{array}{l}\text { Gingival } \\
\text { İndeks }\end{array}$} & $0-6$ & $0.11 \pm 0.19$ & $0.42 \pm 0.49$ & 0.255 \\
\hline & $7-12$ & $0.83 \pm 0.58$ & $0.69 \pm 0.46$ & 0.442 \\
\hline & $13-18$ & $0.67 \pm 0.80$ & $1.04 \pm 0.49$ & 0.169 \\
\hline
\end{tabular}

\section{TARTIŞMA}

Ağı ve diş sağlığı, genel sağlığın ayrılmaz bir parçasıdır ${ }^{19,20}$. Sistemik hastalıkların ağız içi bulgularının bilinmesi, hastalığın erken tanısına yardımcı olabildiği gibi ağız hastalıklarına yanlış tanı konmasını önleyip uygun tedavi planlamasının geliştirilmesine de imkân sağlamaktadır.

Endokrin sistem çeşitli hormonların salgılanmasından sorumludur ve homeostazın sağlanması ve devam ettirilmesiyle yakından ilişkilidir ${ }^{21}$. Çocuklarda çeşitli endokrin bozuklukları arasında en sık gözlenen tiroid bozuklukları olup, tiroid bozuklukları arasında da en yaygın olarak gözlenen hipotiroidittir ${ }^{22,23}$. Hormonal ve metabolik değişiklikler, genel sağlıkta değişikliklere yol açtığı gibi tükürük bezi fonksiyonlarını da etkilemektedir ${ }^{24}$. Hipotiroiditli hastalarda ağız bulgularının değerlendirildiği sınırlı sayıdaki çalışmada tükürük fonksiyonlarının etkilendiği, diş çürüğü ve periodontal hastalıkların görülme sıklığının arttığ 1 ve liken plenus lezyonlarının görüldüğü rapor edilmiştir ${ }^{12-16}$. Yapılan literatür araştırmasında, hipotiroiditli hastaların ağız sağlığının değerlendirilmesi ile ilgili sınırlı sayıda çalışma olduğu ve bu çalışmaların çoğunlukla yetişkin bireyler üzerinde gerçekleştirildiği görülmektedir ${ }^{12-14,16}$. Ayrıca subklinik hipotiroditli hastaların ağız sağlığı hakkında herhangi bir çalışmaya rastlanmamıştır. Bu nedenle bu araştırmada, subklinik hipotiroiditli çocuk hastaların, çürük, dolgulu ve kayıp dişleri ve periodontal durumu incelenerek ağı sağlığı durumunun değerlendirilmesi ve sağlıklı çocuklarla karşılaştırılması amaçlandı.

Araştırmamızın deney grubu, Eskişehir Osmangazi Üniversitesi Tıp Fakültesi Çocuk Sağlı̆̆ı ve Hastalıkları Anabilim Dalı'na başvuran subklinik hipotiroiditli gönüllü çocuklardan oluşturuldu. Hastaların kesin tanısının tespit edilebilmesi nedeniyle gönüllü çocuklar Tip Fakültesine başvuran ve tiroid hormonları ve klinik değerlendirmeler sonucunda subklinik hipotiroidi tanısı konan ve başka herhangi bir sistemik hastalığı bulunmayanlar arasından seçildi.

Kontrol grubu ise Eskişehir Osmangazi Üniversitesi Diş Hekimliği Fakültesi Çocuk Diş Hekimliği Anabilim Dalı’na ve Eskişehir Osmangazi Üniversitesi Tip Fakültesi Çocuk Sağlığı ve Hastalıkları Anabilim Dalı'na başvuran herhangi bir sistemik hastalığı olmayan sağlıklı çocuklar arasından seçildi. Kontrol grubuna dahil edilen çocukların subklinik hipotiroidi olmadığını desteklemek için sT4 ve TSH kan değerleri çalışılarak subklinik hipotiroidi olmadığı onaylandı. 
Diş çürüğü ve periodontal hastalık görülme sıklığını değerlendiren çalışmalarda farklı yaş gruplarında farklı DMFT değerlerinin ve periodontal hastalık prevalansının rapor edildiği görülmektedir ${ }^{25-29}$. Bu nedenle subklinik hipotiroiditli hastaların ağız ve diş sağlığı hakkında elde edilecek verilerin kontrol grubuyla güvenle karşılaştırılabilmesi için oluşturulan kontrol grubunun da benzer yaş aralığına sahip olması gerektiğinden araştırmamızda önce subklinik hipotiroiditli hastalardan oluşan deney grubu, ardından da deney grubuna benzer yaş aralığındaki sağlıklı çocuklarından oluşan kontrol grubu oluşturuldu.

Hipotiroiditli hastaların ağız bulgularının değerlendirildiği sınırlı sayıdaki çalışmada genellikle tükürük fonksiyonları değerlendirilmiş ${ }^{12,14,16,30-32}$ ve hipotiroiditli hastaların düşük tükürük fonksiyonuna sahip olduğu bildirilmiştir. ${ }^{12,14,16,30-32}$ Tükürük fonksiyonunun azalması diş çürüğü ve periodontal hastalık riskini artırıcı faktörler arasında yer almaktadir ${ }^{33-35}$. Bu nedenle bu araştırmada, subklinik hipotiroiditli çocuk hastaların çürük ve periodontal durumu değerlendirildi.

Araştırmamıza dahil edilen kızların sayısının erkeklerden daha fazla olduğu tespit edildi. Yapılan çalışmalarda subklinik hipotiroidinin kadinlarda erkeklere oranla daha sık gözlendiği bildirilmektedir ${ }^{7-9}$. Araştırmamıza dahil edilen çocuklar arasında kızların daha fazla olmasının subklinik hipotiroidinin kadınlarda daha sık gözlenmesinden kaynaklandığını düşünmekteyiz. Ayrıca istatistiksel değerlendirme sonucu yaş ve cinsiyet açısından her iki grup arasında (deney ve kontrol) anlamlı bir fark gözlenmedi $(\mathrm{p}>0.05)$.

Venkatesh Babu ve Patel15 2-16 yaş aralığındaki tiroid bozukluğuna sahip (\%95 hipotiroiditli, \%5 diğer) çocuklarda DMFT ve dft skorlarının sağlıklı çocuklara oranla istatistiksel olarak anlamlı olmasa da daha yüksek olduğunu saptamışlardır. Al-Rubbaey ve El-Samarraii ${ }^{36}$ de yetişkinlerde yaptıkları çalışmada tiroid difonksiyonuna sahip grubun DMFS değerinin sağlıklı gruptan istatistiksel ola- rak daha yüksek olduğunu bildirmişlerdir. Benzer şekilde araştırmamızda da deney grubunun DMFT değerlerinin kontrol grubundan daha yüksek olduğu ancak aradaki farkın sadece 13-18 yaş grubunda istatistiksel olarak anlamlı olduğu belirlendi $(\mathrm{p}<0.05)$. Bu bulgular 1şığında tiroid disfonksiyonun diş sağlığını olumsuz yönde etkilediğini düşünmekteyiz.

İnterlökin-6 ve tümör nekrozis faktör- $\alpha$ tiroid disfonksiyonunu da içeren farklı patolojik durumlarda farklı dokularda üretilen iki ana proinflamatuar sitokinlerdir ${ }^{37,38}$. Bu sitokinler sistemik dolaşıma katılır ve periodontal dokular da dahil olmak üzere tüm vücuda yayılır ${ }^{35}$. Monea ve ark. ${ }^{35}$ proinflamatuar sitokinlerinin (interlökin-6 ve tümör nekrozis faktör- $\alpha$ ) serum ve tükürükteki seviyesinin tiroid hormonu ile ilişkili periodontitiste önemli bir rol oynadığını bildirmişlerdir. Benzer şekilde Scardina ve Messina ${ }^{33}$ da serum tiroid hormonlarının seviyesindeki azalmanın düşük derecede inflamasyona neden olduğunu ve serumda prostoglandin, sitokin ve metalomatriksproteinazların seviyesinin artmasının periodontal sağlık durumunu kötü yönde etkilediğini, alveoler kemik rezorbsiyonuna neden olduğunu ifade etmişlerdir. De Toledo ve ark. ${ }^{39}$ 1979 yılında yaptıkları çalışmada, hipotiroidizmli ratlarda periodontal ligamentte dejenerasyon ve alveoler kemik rezorbsiyonunu içeren periodontal değişiklikler gözlemlemişlerdir. Tiroid disfonksiyonlu hastalarda periodontal hastalığın ilerleme nedeni hala tam olarak bilinmemektedir. Ancak Feitosa ve ark..$^{40}$ ratlarda kemik kaybı ile ilişkili periodontitiste tiroid hormonlarının etkisini değerlendirdikleri çalışma sonucunda tiroid hormonlarının serum seviyesinin azalmasının periodontal hastalığa neden olabileceğini bildirmişlerdir. Venkatesh Babu ve Patel15 plak ve gingival indeks skorlarının tiroid bozukluğu olan çocuklarda (\%95 hipotiroiditli, \%5 diğer) sağlıklı çocuklardan istatistiksel olarak daha yüksek olduğunu bildirmişlerdir. Benzer şekilde Beriashvili ve ark. ${ }^{30}$ da sağlıklı çocuklarla karşılaştırıldığında tiroid bozukluğu olan çocuklarda periodontal hastalık görülme sıklığının arttığını rapor etmişlerdir. Yetişkin bireylerde yapılan bir çalışmada ise orta 
seviyedeki gingival inflamasyonun tiroid disfonksiyonlu hastalar arasında yaygın olduğu saptanmıştır36. Hanau ve ark. ${ }^{41}$ da yine yetişkinlerde yaptıkları çalışma sonucunda sağlıklı bireyler ile karşılaştırıldığında tiroid bozukluğuna sahip hastaların zayıf periodontal sağllğa ve daha fazla klinik ataşman kaybına sahip olduğunu bulmuşlardır. Buna karşın araştırmamızda plak ve gingival indeks skorları açısından sağlıklı ve subklinik hipotiriditli hastalar arasında istatistiksel olarak anlamlı bir fark olmadığ tespit edildi ( $\mathrm{p}>0.05$ ). Bulgularımızın diğer çalışmalardan farklı olmasının, araştırmamıza sadece subklinik hipotiroiditli hastaların dahil edilmesinden ve çalışma popülasyonunun küçük olmasından kaynaklanabileceğini düşünmekteyiz.

Sonuç olarak bu araştırmaların sınırlamaları dahilinde, subklinik hipotiroiditli çocuk hastalarda diş çürüğü görülme sıklığının sağlıklı çocuklara oranla daha yüksek olduğu ancak periodontal sağlığın etkilenmediği belirlendi. Bununla birlikte, araştırmamızın bulgularının desteklenmesi için daha geniş popülasyonlu çalışmaların yapılması gerektiği kanısındayız.

\section{Açıklamalar}

$\mathrm{Bu}$ araştırma Eskişehir Osmangazi Üniversitesi Bilimsel Araştırma Projeleri Komisyonu tarafından 2017-45A233 proje numarası ile desteklenmiştir.

\section{Yazarların herhangi bir çıkar dayalı ilişkisi yoktur.}


Journal of BSHR 2019;3(3):237-244

TÜLOĞLU, KALİÇOĞLU, KIREL. Subklinik Hipotiroiditli Çocuklarda Ağız Sağlığı

\section{Kaynaklar}

1. Cooper DS. Clinical practice. Subclinical hypothyroidism. N Engl J Med. 2001; 345(4): 260265.

2. Surks MI, Ortiz E, Daniels GH, et al. Subclinical thyroid disease: scientific review and guidelines for diagnosis and management. JAMA. 2004; 291(2): 228-238.

3. Adlin V. Subclinical hypothyroidism: deciding when to treat. Am Fam Physician. 1998; 57(4): 776-780.

4. Wiersinga WM. Adult Hypothyroidism. In: Leslie J De Groot, ed. Thyroid Manager. Online books. 2013. Published in http://www.thyroidmanager.org/

5. Kim YA, Park YJ. Prevalence and risk factors of subclinical thyroid disease. Endocrinol Metab (Seoul). 2014; 29(1): 20-29.

6. Yürekli BȘ, Kabalak T, Altıner S. Subklinik hipotiroidi meselesi: tedavi edilmeli mi edilmemeli mi?. Türkiye Klinikleri J Endocrin. 2016; 11(2): 55-64.

7. Rivolta $G$, Cerutti $R$, Colombo $R$, et al. Prevalence of subclinical hypothyroidism in a population living in the Milan metropolitan area. J Endocrinol Invest. 1999; 22(9): 693-697.

8. Canaris GJ, Manowitz NR, Mayor G, et al. The Colorado thyroid disease prevalence study. Arch Intern Med. 2000; 160(4): 526-534.

9. Bona G, Prodam F, Monzani A. Subclinical hypothyroidism in children: natural history and when to treat. J Clin Res Pediatr Endocrinol. 2013; 5(Suppl 1): 23-28.

10. Baldini IM, Vita A, Mauri MC, et al. Psychopathological and cognitive features in subclinical hypothyroidism. Prog Neuropsychopharmacol Biol Psychiatry. 1997; 21(6): 925-935.

11. Devdhar M, Ousman YH, Burman KD. Hypothyroidism. Endocrinol Metab Clin North Am. 2007; 36(3): 595-615.

12. Chang CP, Shiau YC, Wang JJ, et al. Decreased salivary gland function in patients with autoimmune thyroiditis. Head Neck. 2003; 25(2): 132-137.

13. Lo Muzio L, Santarelli A, Campisi G, et al. Possible link between Hashimoto's thyroiditis and oral lichen planus: a novel association found. Clin Oral Investig. 2013; 17(1): 333-336.

14. Agha-Hosseini F, Shirzad N, Moosavi MS. Evaluation of Xerostomia and salivary flow rate in Hashimoto's Thyroiditis. Med Oral Patol Oral Cir Bucal. 2016; 21(1): e1-5.

15. Venkatesh Babu NS, Patel PB. Oral health status of children suffering from thyroid disorders. J Indian Soc Pedod Prev Dent. 2016; 34(2): 139-144.

16. Syed YA, Reddy BS, Ramamurthy TK, et al. Estimation of salivary parameters among autoimmune thyroiditis patients. J Clin Diagn Res. 2017; 11(7): ZC01-ZC04.

17. Silness J, Löe H. Periodontal disease in pregnancy II. Correlation between oral hygiene and periodontal condition. Acta Odontol Scand. 1964; 22(1): 121-135.

18. Löe $H$. The gingival index, the plaque index and the retention index systems. J Periodontol. 1967; 38(6): 610-616.

19. Genderson MW, Sischo L, Markowitz K, et al. An overview of children's oral health-related quality of life assessment: from scale development to measuring outcomes. Caries Res. 2013 ;47(Suppl 1): 13-21.

20. Jeffcoat $M K$, Jeffcoat RL, Gladowski PA, et al. Impact of periodontal therapy on general health: evidence from insurance data for five systemic conditions. Am J Prev Med. 2014; 47(2): 166-174.

21. Carlos Fabue L, Jiménez Soriano Y, Sarrión Pérez MG. Dental management of patients with endocrine disorders. J Clin Exp Dent. 2010; 2(4): e196-203.

22. Desai MP. Disorders of thyroid gland in India. Indian J Pediatr. 1997; 64(1): 11-20.

23. Desai MP. Thyroid function in children. J Assoc Physicians India. 2011; 59(Suppl): 35-42.
24. Szanto A, Csipo I, Horvath I, et al. Autoantibodies to alfa-fodrin in patients with Hashimoto thyroiditis and Sjögren's syndrome: possible markers for a common secretory disorder. Rheumatol Int. 2008; 28(11): 1169-1172.

25. Yılmaz AB, Orbak R, Çanakçı N, ve ark. Erzurum ve Düzce’de 6- 12 yas grubu bireylerde CPITN, df, dmf indekslerini kullanarak periodontal hastalklar ile diş çürüğünün değerlendirilmesi ve iki bölgenin karșılaștırılması. Atatürk Üniv Diş Hek Fak Derg. 1997; 7(1): 5-11.

26. Bodur H, Bodur A, Yücesoy V, ve ark. İki farkl yaș grubunda diş çürüğü prevelansı ve periodontal durumun değerlendirilmesi. Gazi Üniv Diş Hek Fak Derg. 2004; 21(5): 35-39.

27. Kambek Taşveren S, Yalçın Yeler D, Sözen A, ve ark. 12 yaş grubu çocukların diş firçalama sıklı̆ğ-dmf-t ilişkisi. Atatürk Üniv Diş Hek Fak Derg. 2005; 15(3): 11-14.

28. Gökalp S, Güçiz Doğan B, Tekçiçek $M$, ve ark. Beș, on iki ve on beș yaș çocukların ağız diș sağlı̆̆ profili, Türkiye-2004. Hacettepe Diş Hek Fak Derg. 2007; 31(4): 3-10.

29. Koksal E, Tekcicek M, Yalcin SS, ve ark. Association between anthropometric measurements and dental caries in Turkish school children. Cent Eur J Public Health. 2011; 19(3): 147-151.

30. Beriashvili S, Nikolaishvili M, Mantskava M, et al. Changes in tooth hard tissue mineralization and blood rheology in healthy adolescents and those with thyroid dysfunction. Georgian Med News. 2016; (Issue): 28-34.

31. Persson RE, Persson GR, Kiyak HA, et al. Oral health and medical status in dentate low-income older persons. Spec Care Dentist. 1998; 18(2): 70-77.

32. Muralidharan $D$, Fareed $N$, Pradeep $P V$, et al. Qualitative and quantitative changes in saliva among patients with thyroid dysfunction prior to and following the treatment of the dysfunction. Oral Surg Oral Med Oral Pathol Oral Radiol. 2013; 115(5): 617-623.

33. Scardina GA, Messina P. Modifications of interdental papilla microcirculation: a possible cause of periodontal disease in Hashimoto's thyroiditis? Ann Anat. 2008; 190(3): 258-63.

34. Siqueira WL, Bermejo PR, Mustacchi Z, et al. Buffer capacity, $p H$ and flow rate in salive of children aged 2-60 months with down's syndrome. Clin Oral Investig. 2005; 9(1): 26-29.

35. Monea A, Elod N, Sitaru A, et al. Can thyroid dysfunction induce periodontal disease? Eur Sci J. 2014; 10(15): 74-83.

36. Al-Rubbaey YA, El-Samarrai SK. Oral health status and dental treatment needs in relation to salivary constituents and parameters among a group of patients with thyroid dysfunction. J Bagh College Dentistry. 2010; 22(1): 105-108.

37. Bartalena L, Grasso L, Brogioni S, et al. Serum interleukin-6 in amiodarone-induced thyrotoxicosis. J Clin Endocrinol Metab. 1994; 78(2): 423-427.

38. Sekeroglu MR, Altun ZB, Algün E, ve ark. Serum cytokines and bone metabolism in patients with thyroid dysfunction. Adv Ther. 2006; 23(3): 475-480.

39. De Toledo S, Bozo L, Do Nascimento A, et al. Changes of thyroid gland and periodontal tissues of marmosets related to experimental hypothyroidism. Rev Bras Pesqui Med Biol. 1979; 12(2-3): 141-146.

40. Feitosa DS, Marques MR, Casati MZ, et al. The influence of thyroid hormones on periodontitis-related bone loss and tooth supporting alveolar bone: A histological study in rats. J Periodontal Res. 2009; 44(4): 472-478.

41. Hanau KJ, Naoom E, Mahammed HO. CPITN in Iraqi females with thyroid dysfunction. Mustansiryia Dent J. 2018; 9(1): 99-106. 